\title{
EFFECTS OF OZONE AND ULTRAVIOLET ON PHYSICAL AND OXIDATIVE PROPERTIES IN EDIBLE COATING'S CHICKEN BREAST MEAT
}

\author{
Agus Susilo ${ }^{1)}$, Herly Evanuarini ${ }^{1)}$, Mulia Winirsya Apriliyani ${ }^{1)}$ \\ ${ }^{1)}$ Departemen of Animal Product Technology, Animal Science Faculty, Universitas Brawijaya, Jl. Veteran, Kota \\ Malang, East Java, Indonesia, 65145 \\ *Corresponding Email: muliaapriliyani@ub.ac.id
}

Submitted 15 November 2021; Accepted 28 November 2021

\begin{abstract}
The effects of gaseous ozone exposure on the physical and oxidative properties were evaluated in chicken breast fillets, which were pretreatment of gaseous ozone, ultraviolet, edible coatings and stored at $8^{\circ} \mathrm{C}$ (refrigerator), $27^{\circ} \mathrm{C}$ (closed pack), and $27^{\circ} \mathrm{C}$ (opened pack) for $4 \mathrm{~d}$. The physical and oxidative properties of chicken meat are maintained after preozonation treatment is then applied to the edible coating. $\mathrm{pH}$ of chicken meat given ozone, UV and edible coating and stored at refrigerator that a $\mathrm{pH}$ closest to the normal chicken meat $\mathrm{pH}$ of 5.87. Combination of ozone, UV and edible coating has and the highest water holding capacity value and TBA value but the lowest cooking loss value. The brightness level of chicken meat coated in edible coating and stored at various temperatures showed a difference. The ability to store longer or with an increase in storage temperature, besides that, it can add value to the bioactive antioxidant and antimicrobial components.
\end{abstract}

Key words: Chicken meat; edible coatings; ozone; ultraviolet 


\section{INTRODUCTION}

Along with the increase in the population in Indonesia, there is also an increase in the need for food, including animal food, namely meat. Currently, chicken meat is one of the food ingredients that plays a significant role in the fulfillment of nutritional needs because it has high quality protein and contains amino acids that are desperately needed by the human body. Despite the fact that chicken meat is a costeffective source of animal protein, it is also susceptible to spoilage. Microorganisms that proliferate quickly can alter the quality of chicken flesh. It was also changed to and was shown to be one of the highest risk properties for foodborne diseases (Antunes et al., 2016; Fernley, 2011).

Meat can be infected with pathogenic and spoilage microorganisms in large numbers during periods of slaughter, processing and storage. Washing and rinsing carcasses or reactions are widely used to disinfect meat. Organic acids - maximum, chemical compounds are usually used for this purpose. According to Meat can be treated with lactic acid to reduce microbial contamination of the floor. In chicken processing, carcasses need to be cooled to about $4^{\circ} \mathrm{C}$ in water and / or air immediately after slaughter. The temperature at the showcase at the supermarket is generally $0-8^{\circ} \mathrm{C}$ (Suprayogo, Swarjana and Rudyanto, 2014).

The quality of broiler meat can decrease with the length of storage, both physically, microbiologically and organoleptically. Broiler meat stored at a temperature of $0-4^{\circ} \mathrm{C}$ can last $3 \mathrm{~d}$, while storage at a temperature of about $8^{\circ} \mathrm{C}$ can only last two days, so in the presentation of broiler meat needs to be made integrated planning that can maintain the quality of broiler meat so that the shelf life is longer. Cold storage with temperatures below or above the optimum range of microbial growth will prevent microbes from growing and developing.

Cooling, including storage above or below freezing on fresh meat is one of the traditional preservation methods often used (Zhou, $\mathrm{Xu}$, and Liu, 2010). This research is expected to produce the right broiler meat preservation application technique by knowing the difference in the physical, chemical, and sensory qualities of chicken breast fillets before and after being given the treatment of ozone technology or other treatment.

Meat has been kept in the temperature danger zone (between $5-60^{\circ} \mathrm{C}$ ) for between two and four hours cannot be put back in the refrigerator and must be consumed. The temperature danger zone for four or more hours must be discarded. The physical and chemical quality of chicken breast fillets is maintained after the preliminary treatment of ozone and then the application of edible coating. Longer storage capability as well as increased storage temperature, in addition can then increase the value of antioxidant and antimicrobial bioactive components.

The purpose of the present study was to evaluate the effects of combining ozone, UV, and edible coating on the physical and oxidative properties for evaluating in chicken breast fillets, which were pretreatment of ozone, ultraviolet, and edible coatings then stored at $8^{\circ} \mathrm{C}$ (refrigerator), $27^{\circ} \mathrm{C}$ (closed pack), and $27^{\circ} \mathrm{C}$ (opened pack) for $4 \mathrm{~d}$. The ability to store longer or with an increase in storage temperature, besides that, it can add value to the bioactive antioxidant and antimicrobial components.
*Corresponding author:

Mulia Winirsya Apriliyani

Email: muliaapriliyani@ub.ac.id

Departemen of Animal Product Technology,

Animal Science Faculty, Universitas Brawijaya, J1.

Veteran, Kota Malang, East Java, Indonesia, 65145
How to cite:

Susilo, A., Evanuarini, H., \& Apriliyani, M. W. (2021). Effects of Ozone and Ultraviolet on Physical and Oxidative Properties in Edible Coating's Chicken Breast Meat. Jurnal Ilmu dan Teknologi Hasil Ternak (JITEK), 16 (3), 181-189 


\section{MATERIALS AND METHODS}

Chicken breast fillet (Fiesta) was cut into $5 \times 5 \times 1 \mathrm{~cm}^{2}$ sections weighing $35-45 \mathrm{~g}$ and divided of treatment: $\mathrm{O}=$ ozone treatment; $\mathrm{E}=$ dyeing with casein-chitosan edible coating; $\mathrm{OE}=$ ozone for $30 \mathrm{~min}$; and OUE $=$ ozone + UV + coated. After being given the treatment continued stored at different condition (a temperature of $8^{\circ} \mathrm{C}$ (refrigerator), $27^{\circ} \mathrm{C}$ (closed pack), and $27^{\circ} \mathrm{C}$ (opened pack) for $4 \mathrm{~d}$. The research was performed experimentally using 3 replications for each treatment. The edible coating was based on casein and chitosan. Here are the test variables:

\section{pH}

The $\mathrm{pH}$ value will be seen on the $\mathrm{pH}$ meter after the $\mathrm{pH}$ meter shows a constant number.

\section{Cooking Loss}

The meat sample is weighed about $2 \mathrm{~g}$, then put in polyethylene plastic which is $15 \mathrm{~cm}$ long and $10 \mathrm{~cm}$ wide with a thickness of $0.05 \mathrm{~cm}$, then the plastic is clamped and marked according to the treatment. Put the sample on a water bath and boil at $80^{\circ} \mathrm{C}$ for 30 min. The sample was removed and cooled in running water at room temperature. The sample was removed from the plastic and surface dried with tissue paper without pressing it. The results are then calculated.

Water Holding Capacity (Soeparno, 2005) Weighed $0.5 \mathrm{~g}$ of the sample. Pressed on filter paper Whatman No. 42 which is placed between two glass plates with a load of $35 \mathrm{~kg}$ for $5 \mathrm{~min}$. It is drawn on the paper the wet area of the sample and transferred to the graph paper, from the image the wet area is obtained after deducting the area covered by meat (from the total area). Calculated the binding capacity of water with the formula:

Total Moisture Content $=\frac{b 1-b 2}{g \text { sample }} \times 100 \%$
Note:

mg $\mathrm{H}_{2} \mathrm{O}=\left(\right.$ wet area $\left.\left(\mathrm{cm}^{2}\right): 0.0948\right)-8.0$;

Free moisture content $(\%)=\left(\mathrm{mgH}_{2} \mathrm{O}\right.$ : sample weight) $\times 100 \%$

$\mathrm{WHC}=$ total moisture content $(\%)-$ free moisture content $(\%)$

\section{Meat Color}

The sample is prepared if the liquid is put in a glass. Color reader is turned on. The target reading for $L^{*}, a^{*}, b^{*}$ is specified. The results are recorded on the screen color reader (Yuwono dan Susanto, 1998).

\section{TBA}

The sample was weighed as much as $3 \mathrm{~g}$, quantitatively transferred to a $1000 \mathrm{ml}$ Kjeldahl distillation flask washed with $98.5 \mathrm{ml}$ distilled water and added with $1.5 \mathrm{ml} \mathrm{4N} \mathrm{HCl}$ to $\mathrm{pH} 1.5$. Add boiling stone and antifoam to taste and install a distillation device. The distillation was carried out on high heating until $50 \mathrm{ml}$ of distillate was obtained for $10 \mathrm{~min}$. The distillate obtained was stirred evenly, filtered and transferred as much as $5 \mathrm{ml}$ into a test tube covered with $\mathrm{ml}$ of TBA reagent added and then closed until evenly mixed and heated for $35 \mathrm{~min}$ in boiling water in a water bath. Blanks were made using $5 \mathrm{ml}$ of distilled water and $5 \mathrm{ml}$ of reagents, carried out as a sample. The test tube was cooled with cooling water for $10 \mathrm{~min}$. The absorbance (D) was measured at a wavelength of $528 \mathrm{~nm}$ with blangko solution as the zero point and a sample of $1 \mathrm{~cm}$ in diameter was used. The TBA number is expressed in Malonaldehyde per $\mathrm{kg}$ sample (TBA number $=7.8 \mathrm{D}$ ), calculated by the formula:

$$
\mathrm{TBA}=\frac{7.8 \times D \times 3}{\text { weight of sample }(\text { malonaldehid } / \mathrm{kg})}
$$

\section{Peroxides Value}

The peroxide number is determined by procedure as follows: Oil as much as $10 \mathrm{~g}$ put in a closed Erlenmeyer and $30 \mathrm{ml}$ of mixed acetic acid solvent was added glacial: chloroform $(3: 2 \mathrm{v} / \mathrm{v})$. After the oil dissolves $0.5 \mathrm{ml}$ of saturated KI solution was 
completely added and left for 1 minute while shaking, then added $30 \mathrm{ml}$ of distilled water. The iodine liberated by peroxides titrated with solution standard sodium thiosulfate $\left(\mathrm{Na}_{2} \mathrm{~S}_{2} \mathrm{O}_{3}\right) 0.1015 \mathrm{~N}$ with starch indicator until blue lost. $\mathrm{S}$ is sample titration; $\mathrm{B}$ is blank titration, and $\mathrm{N}$ is normality of $\mathrm{Na}_{2} \mathrm{~S}_{2} \mathrm{O}_{3}$. The peroxide number is given by the calculation formula is as follows:

Peroxides Value $=\frac{m l \mathrm{Na} 2 \mathrm{~S} 2 \mathrm{O} 3 \times N \text { Na2S2O3 } \times 1000}{\text { weight of sample }(\text { gram })}$

\section{Antioxidant Activity}

Samples weighing $10 \mathrm{~g}$ were mashed and then macerated using $95 \%$ ethanol with a ratio of 1:3 and soaked for $24 \mathrm{~h}$ in closed conditions. The soaking product is then filtered and evaporated using a water bath to obtain a thick extract. A total of $1 \mathrm{ml}$ of the extract which was diluted with ethanol were added to $1 \mathrm{ml}$ of DPPH at the same time. The reaction mixture was mixed well and then incubated in the dark for $30 \mathrm{~min}$. The absorbance was measured at a wavelength of
$517 \mathrm{~nm}$ using a UV spectrophotometer (Ismanto dan Subaihah, 2020).

\section{RESULTS AND DISSCUSION}

\section{pH, Cooking Loss, and Water Holding Capacity (WHC)}

The results of the analysis of variance on $\mathrm{pH}$, cooking Loss and WHC showed significantly $(\mathrm{P}<0,05)$, can be seen in Table 1. $\mathrm{pH}$ of chicken meat given OUE and stored at refrigerator that a $\mathrm{pH}$ closest to the normal chicken meat $\mathrm{pH}$ of 5.87 . The normal $\mathrm{pH}$ of chicken meat ranges from 5.96-6.07 (Irmayani et al.,2019).

The use of casein-chitosan edible coating solution can reduce bacteria oxidizing nonprotein nitrogen denominations (Valdez et al., 2017). The $\mathrm{pH}$ values of all groups exceeded during the keeping time, by action of microbial or endogenous enzymes like lipase and protease that cause an exceed in trimethylamine and ammonia (Gilani et al., 2015).

Table 1. Data of $\mathrm{pH}$, cooking loss and WHC

\begin{tabular}{lcccc}
\hline & & \multicolumn{3}{c}{ Storage Condition } \\
\cline { 3 - 5 } & Treatment & $8^{\circ} \mathrm{C}$ & $\begin{array}{c}27^{\circ} \mathrm{C} \\
(\text { Closed pack })\end{array}$ & $\begin{array}{c}27^{\circ} \mathrm{C} \\
(\text { Opened pack })\end{array}$ \\
\cline { 3 - 5 } $\mathrm{pH}$ & $\mathrm{O}$ & $5.71^{\mathrm{c}, \mathrm{A}} \pm 0.03$ & $4.97^{\mathrm{a}, \mathrm{A}} \pm 0.03$ & $5.33^{\mathrm{b}, \mathrm{A}} \pm 0.03$ \\
& $\mathrm{E}$ & $5.73^{\mathrm{c}, \mathrm{B}} \pm 0.04$ & $5.05^{\mathrm{a}, \mathrm{B}} \pm 0.04$ & $5.41^{\mathrm{b}, \mathrm{B}} \pm 0.04$ \\
& OE & $5.73^{\mathrm{c}, \mathrm{C}} \pm 0.03$ & $5.11^{\mathrm{a}, \mathrm{C}} \pm 0.03$ & $5.47^{\mathrm{b}, \mathrm{C}} \pm 0.03$ \\
& OUE & $5.88^{\mathrm{c}, \mathrm{D}} \pm 0.03$ & $5.46^{\mathrm{a}, \mathrm{D}} \pm 0.03$ & $5.79^{\mathrm{b}, \mathrm{D}} \pm 0.03$ \\
\hline Cooking Loss & O & $33.10^{\mathrm{a}, \mathrm{D}} \pm 0.11$ & $42.51^{\mathrm{c}, \mathrm{D}} \pm 0.15$ & $39.31^{\mathrm{b}, \mathrm{D}} \pm 0.13$ \\
& $\mathrm{E}$ & $32.87^{\mathrm{a}, \mathrm{C}} \pm 0.16$ & $40.67^{\mathrm{c}, \mathrm{C}} \pm 0.08$ & $37.60^{\mathrm{b}, \mathrm{C}} \pm 0.07$ \\
& OE & $32.70^{\mathrm{a}, \mathrm{B}} \pm 0.10$ & $39.57^{\mathrm{c}, \mathrm{B}} \pm 0.08$ & $36.65^{\mathrm{b}, \mathrm{B}} \pm 0.07$ \\
& OUE & $31.72^{\mathrm{a}, \mathrm{A}} \pm 0.24$ & $35.28^{\mathrm{c}, \mathrm{A}} \pm 0.22$ & $33.37^{\mathrm{b}, \mathrm{A}} \pm 0.16$ \\
\hline WHC & O & $4180^{\mathrm{c}, \mathrm{A}} \pm 0.96$ & $32.08^{\mathrm{a}, \mathrm{A}} \pm 0.46$ & $36.65^{\mathrm{b}, \mathrm{A}} \pm 0.34$ \\
& $\mathrm{E}$ & $42.61^{\mathrm{c}, \mathrm{B}} \pm 0.53$ & $33.42^{\mathrm{a}, \mathrm{B}} \pm 0.53$ & $37.65^{\mathrm{b}, \mathrm{B}} \pm 0.75$ \\
& OE & $43.10^{\mathrm{c}, \mathrm{C}} \pm 1.42$ & $34.41^{\mathrm{a}, \mathrm{C}} \pm 0.23$ & $38.86^{\mathrm{b}, \mathrm{C}} \pm 0.15$ \\
& OUE & $46.50^{\mathrm{c}, \mathrm{D}} \pm 0.35$ & $41.52^{\mathrm{a}, \mathrm{D}} \pm 0.27$ & $42.76^{\mathrm{b}, \mathrm{D}} \pm 1.04$ \\
\hline
\end{tabular}

Different lowercase letter indicates significant difference at $\mathrm{P}<0.05$ in each storage condition; different uppercase letter indicates significant difference at $\mathrm{P}<0.05$ in each treatment; $\mathrm{O}=$ ozone treatment; $\mathrm{E}=$ dyeing with casein-chitosan edible coating; $\mathrm{OE}=$ ozone for $30 \mathrm{~min}$; and OUE $=$ ozone $+\mathrm{UV}+$ coated . 
OUE has the lowest cooking loss value and the highest cooking loss value in ozone treatment $(\mathrm{O})$. Meat with lower cooking loss has a relatively better quality than meat with greater cooking loss because of losing nutrients during the cooking process (Rohim et al., 2016). The combination of ozone, UV radiation and storage at refrigerator temperature can suppress the rate of damage to chicken meat. The combinations of UV-C and edible coatings contributed to cell integrity and reduced fruit tissues' electrolyte leakage. Electrolyte leakage is related to membrane permeability and it gradually increases with ripening or aging. UV-C treatment might have induced biological stress and trigger defense mechanisms in plant materials. The initiation of polyamines accumulation in fruit tissue due to UV irradiation could prevent membrane damage (Abbasi et al., 2015). The ultraviolet light did not produce adverse effect on chitosan or carrageenan- based coating (Lin et al., 2017). The highest WHC is in OUE. The water supply of meat about 20-60\% (Lapase et al., 2016). Based on the chart, it can be known that the combination treatment of ozone, UV radiation, and storage at refrigerator temperature is able to maintain the value of meat proteins.

\section{Color}

The results showed that the brightness level of chicken meat coated in edible coating and stored at various temperatures showed a difference, can be seen in Table 2 . The storage treatment at refrigerator showed $L^{*}$ value of the lighter meat. In other hand, storage at opened temperatures causes the color of chicken meat to be darker than storage at other temperatures. The redness $\left(a^{*}\right)$ value will be also the darker the color than storage at other temperatures. The yellowness $\left(b^{*}\right)$ value will be the brighter the color.

Table 2. Data of color

\begin{tabular}{lcccc}
\hline & & \multicolumn{3}{c}{ Storage Condition } \\
\cline { 3 - 5 } & Treatment & $8^{\mathrm{o} C}$ & $\begin{array}{c}27^{\circ} \mathrm{C} \\
(\text { Closed pack })\end{array}$ & $\begin{array}{c}27^{\circ} \mathrm{C} \\
(\text { Opened pack })\end{array}$ \\
\hline $\begin{array}{lccc}\text { Lightness } \\
\left(L^{*}\right)\end{array}$ & $\mathrm{O}$ & $64.69^{\mathrm{c}, \mathrm{A}} \pm 1.61$ & $56.60^{\mathrm{a}, \mathrm{A}} \pm 1.63$ & $60.48^{\mathrm{b}, \mathrm{A}} \pm 1.62$ \\
& $\mathrm{E}$ & $66.31^{\mathrm{c}, \mathrm{B}} \pm 1.21$ & $59.72^{\mathrm{a}, \mathrm{B}} \pm 1.20$ & $63.01^{\mathrm{b}, \mathrm{B}} \pm 1.20$ \\
& OE & $66.72^{\mathrm{c}, \mathrm{B}} \pm 1.24$ & $60.84^{\mathrm{a}, \mathrm{B}} \pm 1.24$ & $63.82^{\mathrm{b}, \mathrm{B}} \pm 1.24$ \\
Redness & OUE & $70.60^{\mathrm{c}, \mathrm{C}} \pm 0.80$ & $68.69^{\mathrm{a}, \mathrm{C}} \pm 0.82$ & $69.91^{\mathrm{b}, \mathrm{C}} \pm 0.82$ \\
$\left(a^{*}\right)$ & $\mathrm{O}$ & $21.42^{\mathrm{a}, \mathrm{C}} \pm 0.48$ & $29.40^{\mathrm{c}, \mathrm{C}} \pm 1.05$ & $25.98^{\mathrm{b}, \mathrm{C}} \pm 1.04$ \\
& $\mathrm{E}$ & $19.99^{\mathrm{a}, \mathrm{B}} \pm 0.83$ & $26.18^{\mathrm{c}, \mathrm{B}} \pm 1.19$ & $23.39^{\mathrm{b}, \mathrm{B}} \pm 1.05$ \\
& OE & $19.91^{\mathrm{a}, \mathrm{C}} \pm 0.79$ & $25.23^{\mathrm{c}, \mathrm{B}} \pm 1.08$ & $22.94^{\mathrm{b}, \mathrm{B}} \pm 1.09$ \\
Yellowness & OUE & $16.68^{\mathrm{a}, \mathrm{A}} \pm 0.55$ & $20.45^{\mathrm{c}, \mathrm{A}} \pm 2.78$ & $17.59^{\mathrm{b}, \mathrm{A}} \pm 0.56$ \\
$\left(b^{*}\right)$ & $\mathrm{O}$ & $22.83^{\mathrm{c}, \mathrm{A}} \pm 0.80$ & $15.95^{\mathrm{a}, \mathrm{A}} \pm 0.67$ & $18.63^{\mathrm{b}, \mathrm{A}} \pm 0.80$ \\
& $\mathrm{E}$ & $23.87^{\mathrm{c}, \mathrm{B}} \pm 0.56$ & $17.75^{\mathrm{a}, \mathrm{B}} \pm 0.62$ & $20.43^{\mathrm{b}, \mathrm{B}} \pm 0.62$ \\
& OE & $24.00^{\mathrm{c}, \mathrm{C}} \pm 0.68$ & $19.51^{\mathrm{a}, \mathrm{C}} \pm 0.67$ & $21.59^{\mathrm{b}, \mathrm{C}} \pm 0.68$ \\
& OUE & $25.51^{\mathrm{c}, \mathrm{D}} \pm 0.42$ & $23.78^{\mathrm{a}, \mathrm{D}} \pm 0.49$ & $24.91^{\mathrm{b}, \mathrm{D}} \pm 0.43$ \\
\hline
\end{tabular}

Different lowercase letter indicates significant difference at $\mathrm{P}<0.05$ in each storage condition; different uppercase letter indicates significant difference at $\mathrm{P}<0.05$ in each treatment; $\mathrm{O}=$ ozone treatment; $\mathrm{E}=$ dyeing with casein-chitosan edible coating; $\mathrm{OE}=$ ozone for $30 \mathrm{~min}$; and OUE $=$ ozone + UV + coated . 
Color is one of the important indicators that consumers consider in choosing chicken meat. The color of fresh chicken meat is yellowish white, caused by provitamin, which is found in meat fats and oxymyoglobin pigments. Oxymyoglobin pigment is an important pigment in fresh meat, it is only found on the surface and describes the color of the meat (Rohim et al., 2016). In comparison to other, chicken meat has lower myoglobin concentrations (Mir et $a l ., 2017)$ and the color of fresh chicken meat is gray or white (Taran et al., 2015). Whereas, based on Apriliyani et al. (2021) that casein chitosan can block air contact in chicken meat, to prevent the darkening the color.

\section{TBA value, Peroxide Value, and Antioxidant Activity}

TBA results of chicken meat coated by edible coating showed that it was significantly $(\mathrm{P}<0.05)$ on TBA value (can be seen in Figure 1), peroxide value, and antioxidant activity. OUE showed the lowest TBA value while control treatment ozone $(\mathrm{O})$ results in the highest TBA value in various treatments. Malonaldehydes are the result of peroxide breakdown that can be identified by TBA analysis. The higher of the TBA means higher fat oxidation (Wariyah and Riyanto, 2018). TBA numbers obtained for similar fresh samples. The highest fat oxidation occurs in control treatments stored at open temperatures, while fat oxidation is lowest in the combination treatment between ozone use, UV radiation, and storage at refrigerator temperatures.

This combination treatment is the best treatment to defend chicken meat from fat oxidation. TBARS value for all kinds of beef patties (was added $0.02 \%$ butylated hydroxytoluene; $0.05 \%$ ascorbic acid; $0.1 \%$ clove extract) was significantly (Zahid et al., 2020). The increase for TBARS value for the control could be due to the origination of increased MDA that has been considered as secondary products for lipid oxidization (Zhang et al., 2016).

\section{TBA}

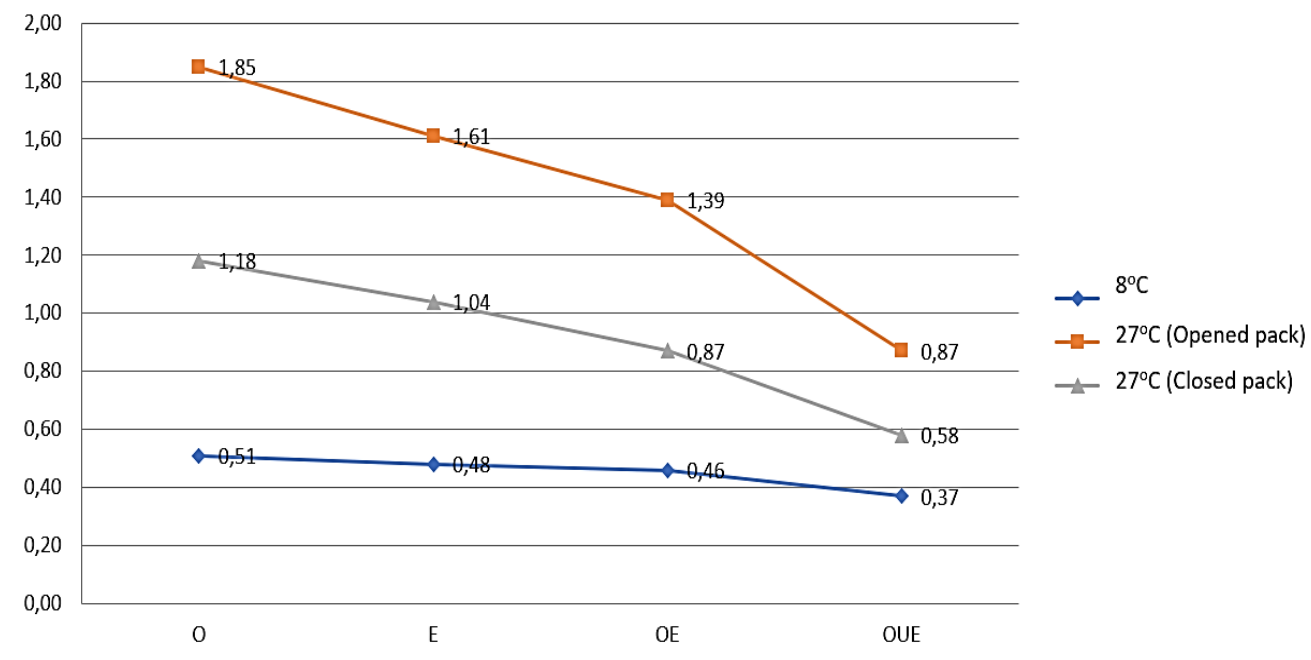

Figure 1. Graphic of TBA value 
Table 3. Peroxides Value and Antioxidant of Different Treatment

\begin{tabular}{|c|c|c|c|c|}
\hline & \multirow[b]{2}{*}{ Treatment } & \multicolumn{3}{|c|}{ Storage Condition } \\
\hline & & $8^{\circ} \mathrm{C}$ & $\begin{array}{c}27^{\circ} \mathrm{C} \\
\text { (Closed pack) }\end{array}$ & $\begin{array}{c}27^{\circ} \mathrm{C} \\
\text { (Opened pack) }\end{array}$ \\
\hline \multirow[t]{4}{*}{ Peroxides Value } & $\mathrm{O}$ & $0.66^{\mathrm{a}, \mathrm{D}} \pm 0.12$ & $5.27^{\mathrm{c}, \mathrm{D}} \pm 0.11$ & $1.87^{\mathrm{b}, \mathrm{D}} \pm 0.12$ \\
\hline & $\mathrm{E}$ & $0.61^{\mathrm{a}, \mathrm{C}} \pm 0.20$ & $4.57^{\mathrm{c}, \mathrm{C}} \pm 0.20$ & $1.60^{\mathrm{b}, \mathrm{C}} \pm 0.20$ \\
\hline & $\mathrm{OE}$ & $0.46^{\mathrm{a}, \mathrm{B}} \pm 0.12$ & $3.86^{\mathrm{c}, \mathrm{B}} \pm 0.11$ & $1.27^{\mathrm{b}, \mathrm{B}} \pm 0.12$ \\
\hline & OUE & $0.26^{\mathrm{a}, \mathrm{A}} \pm 0.11$ & $1.66^{\mathrm{c}, \mathrm{A}} \pm 0.12$ & $0.67^{\mathrm{b}, \mathrm{A}} \pm 0.12$ \\
\hline Antioxidant & $\mathrm{O}$ & $51.32^{\mathrm{c}, \mathrm{A}} \pm 0.93$ & $34.31^{\mathrm{a}, \mathrm{A}} \pm 0.93$ & $44.71^{\mathrm{b}, \mathrm{A}} \pm 0.93$ \\
\hline \multirow[t]{3}{*}{ Activity } & $\mathrm{E}$ & $52.14^{\mathrm{c}, \mathrm{B}} \pm 0.91$ & $37.46^{\mathrm{a}, \mathrm{B}} \pm 0.82$ & $46.47^{\mathrm{b}, \mathrm{B}} \pm 0.91$ \\
\hline & $\mathrm{OE}$ & $52.49^{\mathrm{c}, \mathrm{C}} \pm 1.14$ & $39.46^{\mathrm{a}, \mathrm{C}} \pm 1.16$ & $47.57^{\mathrm{b}, \mathrm{C}} \pm 1.14$ \\
\hline & OUE & $55.89^{\mathrm{c}, \mathrm{D}} \pm 1.04$ & $51.16^{\mathrm{a}, \mathrm{D}} \pm 1.04$ & $54.19^{\mathrm{b}, \mathrm{D}} \pm 1.04$ \\
\hline
\end{tabular}

Different lowercase letter indicates significant difference at $\mathrm{P}<0.05$ in each storage condition; different uppercase letter indicates significant difference at $\mathrm{P}<0.05$ in each treatment; $\mathrm{O}=$ ozone treatment; $\mathrm{E}=$ dyeing with casein-chitosan edible coating; $\mathrm{OE}=$ ozone for $30 \mathrm{~min}$; and OUE $=$ ozone $+\mathrm{UV}+$ coated .

The results showed that the peroxides value and antioxidant of chicken meat coated in edible coating and stored at various temperatures showed a difference, can be seen in Table 3. Ozone supported lipid oxidation in chicken breast meat. The lowest peroxide number in refrigerator storage and the highest peroxide number on open temperature storage. The number of peroxides is an index of the amount of fat that has undergone oxidation. Oxidation is the process of forming free radicals i.e., fat molecules containing unsaturated fatty acids are oxidized and become rancid (Susilo et al., 2019). Fat hydrolysis affected by water activity (Aw), the mechanism of hydrolysis and oxidation of fats starting with the rise of free fatty acids then fatty acids will soon be oxidized into peroxides (Wariyah and Riyanto, 2018). High peroxides values are definite indication of rancid fat, but moderate values maybe the result of depletion of peroxides after reaching high concentration. Low peroxide values may also be obtained for any extremely rancid products, again because the peroxides initially formed have all undergone further oxidation (Levere, 2004; Gotoh and Wada, 2006). The peroxidation of meat fat can be inhibited by using a combination of ozone, UV light, and refrigeration. In both chicken and duck breast, ozone successfully inhibited bacteria development, with less effect on oxidative degradation in chicken breast (Muhlisin et al., 2016).

\section{CONCLUSION}

This research shows the effectiveness of chicken breast preservation as preliminary treatment are combination of ozone, UV, then the application of edible coating. The use of this combination would be a good alternative to keep food for longer and reduce the risk of contamination.

\section{ACKNOWLEDGMENT}

This research was supported by 2021 Research Grant from Faculty of Animal Science Universitas Brawijaya.

\section{REFERENCES}

Antunes, P., Mourão, J., Campos, J., \& Peixe, L. (2016). Salmonellosis: the role of poultry meat. Clinical Microbiology and Infection, 22(2), 110-121. https://doi.org/10.1016/j.cm i.2015.12.004

Apriliyani, M. W., Manab, A., Puspitawati Rahayu, P., Jannah, M., Hidayah, P. 
N., \& Firdiatila, F. F. (2021). Effect of casein-chitosan edible coating on the Physicochemical and microbiological characteristics of broiler meat at storage $8^{\circ} \mathrm{C}$. Advances in Food Science, Sustainable Agriculture and Agroindustrial Engineering, 4(1), 817. https://doi.org/10.21776/ub.afssa ae.2021.004.01.2

Bazargani-Gilani, B., Aliakbarlu, J., \& Tajik, H. (2015). Effect of pomegranate juice dipping and chitosan coating enriched with Zataria multiflora Boiss essential oil on the shelf-life of chicken meat during refrigerated storage. Innovative Food Science \& Emerging Technologies, 29, 280-287. https://doi.org/10.1016/ j.ifset.2015.04.007

Fearnley, E., Raupach, J., Lagala, F., \& Cameron, S. (2011). Salmonella in chicken meat, eggs and humans; Adelaide, South Australia, 2008. International Journal of Food Microbiology, 146(3), 219-227. https: //doi.org/10.1016/j.ijfoodmicro.2011. 02.004

Irmayani, I., Rasbawati, R., Novieta, I. D., \& Nurliani, N. (2019). Analisis cemaran mikroba dan nilai $\mathrm{pH}$ daging ayam broiler di pasar tradisional lakessi kota parepare. Jurnal Galung Tropika, 8(1), 1-8. https://doi.org/ $10.31850 /$ jgt.v8i1.431

Ismanto, A., \& Subaihah, S. (2020). Sifat fisik, organoleptic dan aktivitas antioksidan sosis ayam dengan penambahan ekstrak daun sirsak (Annona muricata l.). Jurnal Ilmu Peternakan Dan Veteriner Tropis (Journal of Tropical Animal and Veterinary Science), 10(1), 45-54. https ://doi.org/10.46549/jipvet.v10i1.84

Lapase, O. A., Gumilar, J., \& Tanwiriah, W. (2016). Kualitas fisik (daya ikat air, susut masak, dan keempukan) daging paha ayam sentul akibat lama perebusan. Student's e Journals, 5(4).

Lin, M. G., Lasekan, O., Saari, N., \& Khairunniza-Bejo, S. (2017). The effect of the application of edible coatings on or before ultraviolet treatment on postharvested longan fruits. Journal of Food Quality, 2017, 1-11. https://doi.org/10.1155/2017/5 454263

Mir, N. A., Rafiq, A., Kumar, F., Singh, V., \& Shukla, V. (2017). Determinants of broiler chicken meat quality and factors affecting them: a review. Journal of Food Science and Technology, 54(10), 2997-3009. https://doi.org/10.1007/s13197-0172789-Z

Morachis-Valdez, A. G., Gómez-Oliván, L. M., García-Argueta, I., HernándezNavarro, M. D., Díaz-Bandera, D., \& Dublán-García, O. (2017). Effect of chitosan edible coating on the biochemical and physical characteristics of carp fillet (Cyprinus carpio) stored at $-18^{\circ} \mathrm{C}$. International Journal of Food Science, 2017, 1-10. https://doi.org/10.1155/2017/2812483

Muhlisin, M., Utama, D. T., Lee, J. H., Choi, J. H., \& Lee, S. K. (2016). Effects of gaseous ozone exposure on bacterial counts and oxidative properties in chicken and duck breast meat. Korean Journal for Food Science of Animal Resources, 36(3), 405-411. https:// doi.org/10.5851/kosfa.2016.36.3.405

Rohim, M. N., Bintoro, V. P., \& I, E. (2016). Uji (warna, tekstur dan susut masak) daging ayam pedaging Lohman yang diberi tepung daun keyambang (Salvinia molesta) sebagai campuran pakan. Jurnal Pengembangan Penyuluhan Pertanian, 13(23).

Soeparno. (2005). Ilmu Nutrisi Dan Gizi Daging. Gadjah Mada University Press.

Suprayogo, D., Suarjana, I., \& Rudyanto, M. (2014). Lama penyimpanan daging broiler terhadap jumlah cemaran coliform pada showcase pasar-pasar swalayan di Denpasar. Indonesia Medicus Veterinus, 3(2).

Susilo, A., Rosyidi, D., Jaya, F., \& Apriliyani, M. W. (2019). Dasar 
Teknologi Hasil Ternak. UB Press.

Taran, S. Y., Ballo, V. J., \& Sinlae, M. (2015). Pengaruh pemberian tepung bonggol pisang dan tepung daun kelor sebagai pengganti jagung terhadap warna, rasa dan keempukan daging ayam broiler. Jurnal Nukleus Peternakan, 2(1), 67-74. https://doi. org/10.35508/NUKLEUS.V2I1.732

Wariyah, C., \& Riyanto, R. (2018). Efek antioksidatif dan akseptabilitas bakso daging ayam ras dengan penambahan gel lidah buaya. Agritech, 38(2), 125-
132. https://doi.org/10.22146/agritech .31850

Yuwono, S. S., \& Susanto, T. (1998). Pengujian Fisik Pangan. Universitas Brawijaya.

Zhang, H., Wu, J., \& Guo, X. (2016). Effects of antimicrobial and antioxidant activities of spice extracts on raw chicken meat quality. Food Science and Human Wellness, 5(1), 39-48. https://doi.org/10.1016/j.fshw.2015.1 1.003 